\title{
The Multiplicities within Capitalist Rule and the Articulation of Struggles
}

\author{
Michael Hardt and Toni Negri
}

\begin{abstract}
This contribution is part of a debate between Michael Hardt/Toni Negri and David Harvey on the occasion of Marx's bicentenary (May 5, 2018). The discussion focuses on the question of what capitalism looks like today and how it can best be challenged. In this article, Hardt and Negri respond to David Harvey's article "Universal Alienation".
\end{abstract}

Keywords: Marx, bicentenary, 200th anniversary, capitalism, exploitation, praxis, alienation, formal subsumption, real subsumption

\section{Introduction}

David Harvey's analysis of universal alienation provides a wonderful basis for investigation and suggests important indices for political action. The interpretative trajectory he proposes, which extends from Marx's analysis of alienation in the 1844 Economic and Philosophic Manuscripts (Marx 1844) to his usage in the Grundrisse (Marx $1857 / 58)$, opens us the analysis to a wide social field. As do other interpreters, Harvey uses the concept of alienation to characterise the objectification of our subjective capacities at work and thus to name a profound dissatisfaction and discontent in contemporary society. He illuminates rightly the exploitative nature - and also the boredom - of many jobs today, such as the "security guard in the shopping mall". This characterisation of alienation at work today, however, seems to lead him in search of "meaningful jobs" and even to look back on "the steelworker in a bustling factory" of yesteryear as a positive reference point. We do not follow Harvey in this evaluation of "meaningful" industrial labour in contrast to today's "meaningless" jobs, but that is really a minor part of his argument.

More significant and truly illuminating is how Harvey extends alienation socially, well beyond the realm of waged labour, to grasp phenomena such as the gentrification of the metropolis and the transformation of urban space into a social factory. The concept of alienation in Harvey's hands also highlights the extension of the webs of debt - individual and state debt, student debt and municipal debt - as a means to blackmail a wide range of social subjects and a weapon to command the future. Furthermore, as the "universal" modifier of alienation indicates, he reads all these phenomena from the standpoint of total social capital and from the perspective of the world market. We need to extend our vision to that level to understand how capital functions across a wide variety of spaces and scales.

What strikes us most about Harvey's essay is a claim that he makes at the very end. It is just and necessary that people revolt against the capitalist system, and people are doing that in a variety of ways. But in order to change the world, he rightly insists, "it is a prerequisite for revolutionary theory that we first understand it". It seems that for Harvey this principle helps explain why a number of recent revolts including Occupy, the Gezi Park movement, and the 2011 UK race rebellion - have been ineffective and points instead toward a different sort of (as yet unspecified) political practice. 
In our view, in contrast, this principle - understand the world before being able to change it - indicates a two part sequence: grasping the multiplicities that exist within capitalist rule and the varied forms that capitalist exploitation takes place in a wide field of domination (which includes axes of race and gender in addition to and in conjunction with varied forms of waged and unwaged labour) poses the need to articulate a range of existing struggles that challenge capitalist rule in different ways.

In order to sketch the importance of some contemporary struggles, then, we will need to explain what we mean by the multiplicities of capitalist rule. And to do that, since this exchange is explicitly in honour of Marx, let's remain in the universe of Marxian terminology.

\section{From Alienation to Formal and Real Subsumption}

Marx's concepts of the formal and real subsumption emphasise some of the same basic characteristics of capital that Harvey finds in universal alienation ${ }^{1}$. In fact, the social world of the real subsumption maps closely to that of universal alienation. But the two concepts of subsumption, formal and real, are together able to illuminate better than alienation the multiplicities of capitalist rule, also providing an avenue to extend the analysis beyond Marx and hence opening up our understanding of range of forms of contemporary anti-capitalist struggle.

Let's start with Marx's account of the concepts. The distinction between formal and real subsumption for Marx (1867, 1019-1038) relies fundamentally on the genesis of labour practices and, specifically, whether they were born outside or within the realm of capitalist rule.

The formal subsumption of labour under capital is characterised by labour practices that are created outside of capitalist rule, such as a method of cutting sugar cane, and are brought under the rule of capital, for instance, by making those cane cutters into wage labourers. The subsumption of labour in such cases is merely formal, according to Marx's way of thinking, because the "substance" of the labour - or, really, the labour process - remains unchanged. The workers, in other words, are performing the same operations; they are just doing so within a new context, a new regime of rule. In the past, we have found it useful to understand the processes of imperialism in line with those of formal subsumption - in line, for instance, with the way that Rosa Luxemburg (1913) in The Accumulation of Capital characterises European imperialisms and their intrinsic violence in terms of an internalisation of the outside, bringing non-capitalist economies and social forms under the rule of capital.

Marx then distinguishes the process of formal subsumption from a real subsumption of labour under capital in which new labour processes are created by capital itself or, rather, within the capitalist social realm. Marx focused on how labour processes are created through the application of science, the implementations of new technologies, and the like. The labour practices are generated within capital and are fundamentally different than those that were imported from outside, and thus Marx often refers to the passage from the formal to the real subsumption as the advent of a "properly capitalist" society.

We find Marx's concepts of formal and real subsumption to be useful in a variety of regards, but we need to extend them beyond his usage in two respects for our argument here. First is required an extension from the real subsumption of labour un-

${ }^{1}$ For Marx's analysis of formal and real subsumption, see "Results of the Immediate Process of Production", included as the appendix to the English version of Capital, Volume 1 (Marx 1867, 943-1084, especially pp. 1019-1038). 
der capital, which Marx analysed, to the real subsumption of society under capital. In the 1970s, one of us (Toni Negri) found it necessary to read Marx's argument in the Grundrisse in this extended fashion when it became clear that the functioning of capitalist rule, and the forms of anti-capitalist struggle, extended well beyond the factory walls and had invested the entire social terrain (see Negri 1991 xvi; 113-134; 142). The real subsumption of society was a means to theorise, on the one hand, in other words, the extraordinarily wide and deep extension of capitalist relations of production throughout the social fabric, especially in the dominant countries. Here is where we can see clearly the point we mentioned earlier where "universal alienation" and "real subsumption" coincide. The concept, on the other hand, was part of an argument that the traditional forms of syndicalist organisation are no longer sufficient and that in order to combat capitalist rule diverse struggles across the social terrain have to be articulated.

It is important to recognise that analyses of contemporary capitalist society in terms of a real subsumption do not indicate a process of social homogenisation - as if being "properly capitalist" in Marx's terms were to imply the elimination of differences. Instead, arguments of a real subsumption must regard capitalist society as composed of multiplicities, a framework in which social differences interact. The recognition that all social relations, not just labour, tend to be subsumed under capital forces us, then, to theorise the dynamics among class, race, gender, and other axes of subordination.

It is also important to resist interpreting the passage from the formal to the real subsumption as an absolute historical passage, which Marx's analysis seems to suggest. In other words, although we find it useful to enlist these terms in a periodization argument - roughly in the 1970s we passed from a society in which the formal subsumption predominated to one in which the real subsumption did - processes of formal subsumption have by no means ceased. Capital is still working on, incorporating, and functioning alongside not just labour practices but also various social forms that come from its "outside".

In this regard, one might say there is a continuing dynamic between processes of formal and real subsumption ${ }^{2}$. Whereas formal subsumption provides a hinge between the present and various pasts, illuminating the relations between capital and its outsides as well as the different paths of capitalist development, real subsumption highlights how capital continually produces and reproduces differences and structures of rule within its domain, through "properly capitalist" means.

We should be clear that we are not presenting this account of the real and formal subsumption as a departure from David Harvey's interpretation. We see our insistence on the multiplicities within capitalist rule here as completely consistent with his work. Indeed, he has long been a leading voice for recognising the differences within capital especially in terms of space, from the metropolis to the global level. Our divergence, if there is one, resides in terms of what kinds of differences are recognised, whether they are internally or externally related, and, most important, what avenues of political praxis are opened by recognition of these multiplicities.

\footnotetext{
${ }^{2}$ Harry Harootunian $(1991,9,38)$ argues, for example, that formal subsumption is the general rule of capitalist development.
} 


\section{Racial Capitalism and Patriarchal Capitalism Between Formal and Real Sub- sumption}

Scholars of racial capitalism and patriarchal capitalism, although they do not use the terms, effectively extend further these analyses of formal and real subsumption. Cedric Robinson, for instance, begins his investigation of racial capitalism by noting that when capitalist relations of production developed in Europe they employed various forms of racism that preceded it, subordinating not only Africans but also the Irish, the Slavs, and various others (Robinson 1983, 9-44). The capitalist mode of production enlisted and deployed - we might say formally subsumed - racial markers and racial hierarchies within its own structures of rule. Robin D. G. Kelley explicates further Robinson's concept: capitalism and racism "did not break from the old order but rather evolved from it to produce a modern world system of 'racial capitalism' dependent on slavery, violence, imperialism, and genocide. Capitalism was 'racial' not because of some conspiracy to divide workers or justify slavery and dispossession, but because racialism had already permeated Western feudal society" (Kelley $2017 a)^{3}$. The fact that race and racial hierarchies pre-existed capital (and were subsequently incorporated and redeployed in capitalist society) provides one means to recognise that race is not an accidental or incidental feature of the capitalist system. Race is constitutive of the capitalist mode of production and essential to the continuing rule of capital. Note that the concept of racial capitalism does not merely invert the priority, that is, refuse that racism be considered as secondary to capital in order to claim that capital is subordinate to racial hierarchies. The point instead is that, on the one hand, racial and capitalist hierarchies are relatively autonomous, neither subordinate to or derivative of the other, and, on the other hand, the two have become intimately intertwined in contemporary society such that the functioning and survival of the one depends on that of the other.

Feminist theories of patriarchal capitalism have long made arguments about the history of capital and patriarchy parallel to those employed by theories of racial capitalism ${ }^{4}$. Like the theorists of racial capitalism, socialist feminists argued that patriarchy long preceded the advent of capital and thus was not its product. The fact that conceptions of gender and structures of gender domination existed previously, however, does not mean that patriarchy is some universal system with the same basic structures throughout history. Instead, patriarchal structures were adopted and transformed within capitalist society, creating, for instance, a new family structure along with a complex and resilient system of sexual divisions of labour. The historical precedence of gender hierarchy, in other words, does not necessitate that it remains autonomous with respect to capitalist rule, but, as it does for the theorists of racial capitalism, such historical accounts provide a vantage point for recognising that gender like race, although thoroughly interwoven with capitalist hierarchies, retains a relative autonomy. The point, as Iris Young argued in the early 1980s, is that in our analyses we must give the structures of patriarchy and capitalism equal weight and relative

${ }^{3}$ See also Kelley's (2017b) illuminating lecture, "What is racial capitalism and why does it matter?".

${ }^{4}$ The historical relation between patriarchy and capital, although no longer a central occupation of feminist theory, was explored in detail by a generation of socialist feminists in the 1970s and 1980s. See, for instance, the responses to Heidi Hartmann's influential (1981) essay, "The Unhappy Marriage of Marxism and Feminism". Many feminists have returned recently to reconsider the debates of the 1970s. For one example, see the essays in Disch (2015). 
independence while still recognizing their mutually constitutive nature and thereby demonstrating that capitalism is essentially patriarchal (Young 1981, especially pp. $46,64)^{5}$.

There is much more to the debates over racial and patriarchal capitalism, of course, but for the purpose of our argument here we simply want to highlight a double argument that is shared by these theoretical traditions and that, moreover, furthers our understandings of the contemporary functioning of the formal and real subsumption. On the one hand, racism and patriarchy are not incidental features of the capitalist system and not subordinate to its rule, as if they were merely secondary enemies in the primary struggle against capital. They are relatively autonomous structures that have been subsumed formally within it. One the other hand, racial and gender hierarchies are not historically immutable but instead have been thoroughly transformed, reinvented, and redeployed - that is, really subsumed - within "properly capitalist" society and its global mode of production. These two claims, moreover, of formal and real subsumption, are not contradictory but instead highlight the real multiplicities that exist within capitalist rule. Racism and patriarchy are constitutive of capitalist society and essential to its perseverance in this double sense, between the formal and real subsumption 6 .

We should add, parenthetically, that in our recent work we have tried to investigate these multiple dynamics in terms of the common. Contemporary capitalist circuits of production and reproduction, we claim, function primarily through the extraction and expropriation of the common, both natural forms of the common and, most importantly, socially produced forms of the common. The common is not uniform or homogeneous, of course, but instead a field on which radical differences are expressed and interact, and as such the common is a framework for understanding the multiplicities within capital. But we will have to leave development of this notion to another occasion?.

\section{Intersections of Antiracist, Feminist, and Anticapitalist Struggle}

The stakes for political practice involved in highlighting the multiplicities within capitalist ruling structures should be clear. "By and large," to cite Iris Young writing in the early 1980s again, "socialists do not consider fighting women's oppression as a central aspect of the struggle against capitalism itself" (Young 1981, 64). Parallel arguments regarding race can be found throughout the history of Marxist theory and communist organising, posing anti-racism as an important but external question. In-

${ }^{5}$ Cinzia Arruzza (2014) provides one recent account of this tradition of Marxist feminist theorizing. She attempts to develop a "unified theory" that puts the accent on the determining force of capital and corresponds, in certain respects, to a notion of the real subsumption (without giving significant attention to the formal). "The essential thesis of "unitary theory," she claims, "is that for Marxist feminism, gender oppression and racial oppression do not correspond to two autonomous systems which have their own particular causes: they have become an integral part of capitalist society through a long historical process that has dissolved preceding forms of social life" (Arruzza 2014).

${ }^{6}$ One should at this point reverse the agency in the argument to analyze how, just as capital subsumes patriarchal and racists relations, so too, from different standpoints, they subsume capitalist relations.

${ }^{7}$ For our recent effort to characterize contemporary capitalist production and reproduction in terms of the extraction of the common, see primarily Hardt and Negri $(2017,155-182)$ For brief illustrations of the Standing Rock pipeline protest and the Black Land \& Liberation Initiative in terms of the expropriation of the common, see Hardt (2017). 
stead if, as we argue, the relations among these systems of domination are internal, and if racism, patriarchy, and capital are mutually constitutive, then feminist, antiracist and anti-capitalist struggles must intersect on equal terms. Highlighting the multiplicity within the structures of rule thus helps us recognise the importance and efficacy of a wide range of contemporary struggles and the need to interweave them in practice. And, we should note, a wide range of activists today thoroughly register the importance of this point.

This relation between the multiplicity of analysis and the intersection of struggles is illustrated clearly, for example, in the practices of "women's strike" by the Ni Un Menos-movement in Argentina, Italy, and elsewhere. Ni Una Menos arose in response to femicide and violence against women in all its forms and all its locations in the workplace, in the family, and on the street. Gender violence in general, and femicide in particular, is an expression of patriarchal control in its most vicious and brutal forms, and thus the movement is aimed unequivocally at challenging the structures and practices of patriarchy. But the activists are fully aware that the struggle against gender violence cannot but be also a struggle against capital.

Feminist struggle and anti-capitalist struggle come together clearly in the proposal of strike as a political tool. Argentine Ni Una Menos-activists conceived the women's strike, first, as a tool to politicise violence against women and pose women not just as victims but also powerful subjects. The practice of the strike, second, also poses for them the intimate relation between patriarchy and capital. The strike, Verónica Gago explains, "enabled a mapping of the heterogeneity of labor in a feminist register, valuing and making visible precarious, informal, domestic, and migrant forms of work not as supplementary or as subsidiary to waged labor, but as fundamental to current forms of exploitation and value extraction" (Gago 2018). The standpoint of reproduction has long been a framework for feminist analysis to illuminate the gender hierarchies internal to capitalist social relations and relations of production.

Casting the resulting feminist practice in terms of strike is not to pose an analogy - and thus that women can go on strike in the same way that workers can - but instead to highlight an internal relation: that capital functions through gender hierarchies and cannot function otherwise. Clearly, however, such a strike cannot only take the old industrial form of blocking the factory, but instead must articulate together various forms of refusal, withdrawal, and sabotage in different social spaces. In preparation for the women's strike in Argentina, then, Ni Una Menos conducted a research process of asking in women's factory collectives, student collectives, community collectives, and others: What does it mean to strike where you are? How would you go on strike? And then the women's strike itself weaves together these varied contexts and experiences. In effect, the use of the strike by Ni Una Menos illustrates an important general claim: as production becomes increasingly social, so too the traditional forms of strike must transform into a social strike ${ }^{8}$ (Gago 2018). With their reasoning with regard to formulating their strike, Ni Una Menos makes clear that their struggle against gender violence and against the structures of patriarchy more generally is necessarily also an anti-capitalist struggle in the fullest sense.

We would make a parallel argument regarding various examples of contemporary antiracist struggles, including the various streams of Black Lives Matter in the US and the Fallist student movements in South Africa, Rhodes Must Fall and Fees Must Fall. Activists are well aware in these cases too that racial hierarchy and white supremacy

${ }^{8}$ For our analysis of the sequence social production $\rightarrow$ social unionism $\rightarrow$ social strike, see Hardt and Negri $(2017,147-150)$. 
are intimately interwoven with capitalist rule - from police activity to the prisonindustrial complex, from racialized state policies and labour regimes to racialized regimes of the expropriation of wealth, and so forth. They are interwoven to such a degree that in order to challenge white supremacy one has to also attack capitalist rule and, correspondingly, in order to challenge capitalist rule one has to attack white supremacy. Indeed, any serious threat to racial hierarchies is itself a mortal danger to capital.

One should also insist at this point that labour movements and anti-capitalist movements have to engage more seriously than they have with racial and gender hierarchies, and indeed that anti-racist movements and feminist movements need to be more directly and consciously anti-capitalist. That is undoubtedly important but it is not our primary point here.

\section{From Articulation of Struggles to Constitution of the Multitude}

Our argument here turns, in large part, on whether the relations among capital, white supremacy, and patriarchy are external or internal. If they were external then one might say that, although race and gender permeate capitalist society, the different struggles remain essentially separate. If instead the relations among structures of capitalist, racial, and gender hierarchies were internal - that is, if patriarchy and racism were intrinsic not to capital in the abstract but to the functioning of capital as it has developed historically - then a more profound articulation is not only possible but also necessary ${ }^{9}$. The feminist and anti-racist movements we mentioned earlier are, of course, not only anti-capitalist struggles - they are also against patriarchy, white supremacy, coloniality, and more. But the fact that they are already anti-capitalist and that anti-capitalist struggles also aim at overcoming racial and gender hierarchies signals a basis for articulation.

At this point in the argument one should develop, as a side note, a critique of the concept of solidarity insofar as it relies on an external notion of those relations. After the 1905 revolution in Russia, Rosa Luxemburg criticised the fact that the German proletariat was able only to express "international solidarity with the Russian proletariat", understanding the failed uprising as external to them, and completely unable to recognise that the Russian events were, in fact, internal to their own struggle, "a chapter of their own social and political history" (Luxemburg 1906, 74). Luxemburg certainly disdains the German expressions of sympathy (tinged with condescension) for their poor Russian cousins, but her main point here is about the internal relation among struggles.

Luxemburg's critique of solidarity (and the presumed externality of struggles) translates directly to our argument here. One might form coalitions or express solidarity across the lines of struggles against capital, patriarchy, and white supremacy, but that never alters the fundamental separation. Instead if, as the theoretical standpoints of racial capitalism and patriarchal capitalism maintain, these different avenues of struggle are really internal to one another, then the struggles of others are really diverse chapters of one's own social and political history. De te fabula narratur.

The path toward a revolutionary practice has to pass through an articulation of these avenues of struggle and the many like them. But this articulation is by no

${ }^{9}$ David Roediger gently criticizes David Harvey for his inability to recognize the anti-capitalist nature of the Ferguson struggles, which results, he explains, from Harvey's theoretical distinction between capitalism, which includes gender and race oppression, and capital, which can be understood without reference to them (see Roediger 2017, 1-3). 
means spontaneous or immediate. The theoretical recognition of the multiplicities within capitalist rule and the practical realisation of the intersections among struggles against patriarchy, white supremacy, and capital provide nothing more than a solid point of departure. Articulation requires a process of constitution.

One way to express this point in relation to the Marxist tradition is to insist that one cannot assume class identity as a given and immediately configure political struggle on its basis, but instead one must investigate the nature of class composition today and, moreover, one must "make" the class, that is, embark on a political operation of constitution. Such an investigation should reveal, of course, that racial and gender hierarchies are intrinsic and necessary to the contemporary processes of the production and reproduction of capital and are core elements of capitalist rule, just as the analyses of racial and patriarchal capitalism have revealed. The operation of making or constituting class, then, necessarily involves the articulation of multiple subjectivities that are internally related.

Recognising these multiplicities should make clear, in part, why we have attempted to employ the concept of multitude to interpret and translate the contemporary dynamics of class and to grasp the possibilities of political subjectivity in struggle more generally. First, in line with the point we mentioned only parenthetically above, the multitude produces and reproduces the common, which is one means of indicating the radical multiplicities within capital. Second, and more germane for our argument here, multitude indicates a terrain of political action on which articulation is possible among diverse political subjectivities. By multitude, in other words, we do not intend to name an existing subject or to point merely to sociological differences, but rather to indicate a matrix of possibilities. Third, and finally, the multitude as political subject is the result of a process of constitution, a subject that is internally differentiated but articulated through struggle in common. Multitude thus summarises for us the analytical and political trajectory that extends from the recognition of the multiplicities within capital to the articulation of struggles in a coherent political project.

The multitude may thus be an adequate mode for recognising and developing effective contestation within the society of universal alienation that David Harvey analyses. For this to be the case, one must first highlight, as we have tried to do here, the multiplicities within capital and consequently the potential and necessity of an internal articulation of struggles. This provides, in our view, both a means for appreciating the importance of existing struggles and a framework for increasing and realising their revolutionary potential.

\section{References}

Arruzza, Cinzia. 2015. Remarks on Gender. Viewpoint Magazine 4, September 2, 2014. Accessed 17 April, 2018. https://www.viewpointmag.com/2014/09/02/remarks-on-gender/

Disch, Lisa, ed. 2015. 1970s Feminisms. Special Issue of The South Atlantic Quarterly 114 (4), October 2015.

Gago, Verónica. 2018. "\#WeStrike: Notes Toward A Political Theory of the Feminist Strike. The South Atlantic Quarterly 117 (3), forthcoming.

Hardt, Michael. 2017. Managing Up: Assembly and the New Activism. Art Forum, October 2017. Accessed 17 April, 2018. https://www.artforum.com/print/201708/managing-upassembly-and-the-new-activism-71249

Hardt, Michael and Toni Negri. 2017. Assembly. Oxford: Oxford University Press.

Harootunian, Harry 2015. Marx after Marx: History and Time in the Experience of Capitalism. New York: Columbia University Press. 
Hartmann, Heidi. 1981. The Unhappy Marriage of Marxism and Feminism: Towards a More Progressive Union. In Women and Revolution: A Discussion of the Unhappy Marriage of Marxism and Feminism, edited by Lydia Sargent, 2-42. Boston: South End Press.

Kelley, Robin D. G. 2017a. What Did Cedric Robinson Mean by Racial Capitalism? Boston Review, January 12, 2017. Accessed 17 April, 2018. http://bostonreview.net/race/robin-dg-kelley-what-did-cedric-robinson-mean-racial-capitalism

Kelley, Robin D. G. 2017b. What Is Racial Capitalism and Why Does It Matter? Katz Distinguished Lecture in the Humanities, in Capitalism and Comparative Racialization [seminar], University of Washington, 7 November. Accessed 17 April, 2018. https://simpsoncenter.org/news/2017/10/robin-d-g-kelley-racial-capitalism-nov-7

Luxemburg, Rosa. 1913. The Accumulation of Capital. London: Routledge.

Luxemburg, Rosa. 1906. The Mass Strike, the Political Party, and the Trade Unions. London: Harper.

Marx, Karl. 1867. Capital Volume I. London: Penguin.

Marx, Karl. 1857/58. Grundrisse. London: Penguin.

Marx, Karl. 1844. Economic and Philosophic Manuscripts of 1844. In Marx \& Engels Collected Works (MECW) Volume 3, 229-346. London: Lawrence \& Wishart.

Negri, Toni. 1991. Marx Beyond Marx. New York: Autonomedia.

Robinson, Cedric. 1993. Black Marxism. London: Zed Press.

Roediger, David. 2017. Class, Race, and Marxism. London: Verso.

Young, Iris. 1981. Beyond the Unhappy Marriage: A Critique of the Dual Systems Theory. In Women and Revolution: A Discussion of the Unhappy Marriage of Marxism and Feminism, edited by Lydia Sargent, 43-69. Boston: South End Press.

\section{About the Authors}

Michael Hardt

Michael Hardt teaches in the Literature Program at Duke University and is co-director of the Social Movements Lab. He serves as editor of The South Atlantic Quarterly.

\section{Antonio Negri}

Antonio Negri taught at the University of Padua and the University of Paris VIII. He has been one of the central figures of Italian autonomist Marxism. His work is devoted to studies of political philosophy and the analysis of capitalism and globalization.

Hardt and Negri have co-authored the books Labor of Dionysus (1994), Empire (2000), Multitude (2004), Commonwealth (2009), Declaration (2012), and Assembly (2017). Their books are considered to be among the most influential works in political philosophy today. 